(Житомирський державний університет імені Івана Франка) savaskucukehotmail.com ORCID: 0000-0001-9217-6756

\title{
РЕФОРМУВАННЯ СИСТЕМИ СЕРЕДНЬОЇ ОСВІТИ ТУРЕЧЧИНИ НА СУЧАСНОМУ ЕТАПІ: ОРГАНІЗАЦІЯ ТА УПРАВЛІННЯ
}

Стаття присвячена аналізу реформ середньої освіти Туреччини на сучасному етапі. Автор узагальнює проиеси структурування освіти на всіх державних рівнях, розглядає вплив держави на реформування загальної середньої освіти, визначає причинно-наслідкові зв 'язки основних рис інновачійних освітніх процесів в структурі системи освіти, ї̈ змісті, иляхах управління та фінансування, контролю та оцінювання знань, умінь учнів загальноосвітніх закладів, аналізує вплив соціально-економічної ситуації Туреччини на становлення загальної середньої освіти.

Ключові слова: освіта, загальна середня освіта, освітні реформи, демократизащія, націоналізація.

Постановка проблеми у загальному вигляді. Розвиток суспільства пред'являє високі вимоги до підготовки конкурентоспроможних випускників освітніх закладів, до рівня їх здатності вирішувати науково-технічні, інноваційні, управлінські та інші завдання. Розвиток середньої освіти в Туреччині здійснюється в напрямку реалізації пріоритетних фундаментальних досліджень на базі сучасних технологічних платформ. Головним засобом розвитку будь-якої системи освіти $є$ реформи та інноваційні вдосконалення. Останні роки XX століття характеризуються спробою Туреччини удосконалити свою систему освіти, тому глибока реформа освіти в Туреччині, яка розпочалася в 90-х роках ХX століття, охопила структуру системи освіти, їі зміст, управління та фінансування, а також систему контролю та оцінювання компетенцій, знань та умінь учнів.

Інтернаціоналізація освітнього простору в умовах соціально-економічного й культурного зближення європейських країн, що детермінує необхідність критичного вивчення досвіду організації реформування системи освіти у різних країнах з метою використання кращих світових надбань та усвідомлення проблем у цій сфері суспільного буття. Важливим для сучасних педагогічних досліджень у цьому контексті можна вважати досвід Туреччини, яка в умовах динамічного суспільно-політичного розвитку приділяє багато уваги створенню якісної системи освіти.

Якщо протягом ХХ століття Туреччина була відома своєю нестабільністю, то на сьогодні ії економіка є багатообіцяючою завдяки середньому класу з міцними позиціями, чітким основам ведення бізнесу і перспективним інноваційним кластерам [1]. У ст. 60 Конституції Турецької Республіки записано, що кожен громадянин має право на соціальне забезпечення, держава вживає необхідних заходів щодо того, щоб добитися цього, і створює та модернізує відповідні організації [2]. Поетапні кроки реформування системи освіти Туреччини прослідковуються у низці законопроектів, зокрема у "Законі про вищу освіту", "Постанові про академічну оцінку та покращення якості в закладах вищої освіти", "Законі про організацію та обов'язки Міністерства національної освіти", "Законі про державне фінансове управління та контроль", "Постанові про наглядову раду Міністерства національної освіти", в яких окреслено основні заходи, спрямовані реформування системи освіти країни $[3 ; 4 ; 5 ; 6]$.

Порівняльні педагогічні розвідки мають виявити проблеми та зміни, що відбуваються в системі освіті Туреччини на тлі загальносвітових тенденцій.

Зв'язок із важливими науковими і практичними завданнями. У науковій літературі накопичено досвід досліджень проблем реформування освіти в Свропі та світі, зокрема: особливостям інтегративних процесів у професійно-технічній школі (Р. Гуревич, Б. Камінський, Н. Ничкало); розвитку системи освіти Туреччини присвячені дослідження А. Газізової, Ю. Лі, С. Сапожнікова, С. Усманової та ін., становленню освіти Туреччини Й. Акюз, А. Барблан, С. Іхсаноглу, Т. Коротько та ін., проблемам якості освіти Туреччини Н. Борахан, К. Гуруз, Р. Кайнар, Ф. Мізікаджи, М. Озден, А. Озджан, С. Сомел та ін.

Виклад основного матеріалу 3 обгрунтуванням отриманих наукових результатів. Кінець ХX століття - це період великих змін у турецькій економіці, а також у політичних та соціальних структурах [7]. Звичайно, реформи не могли не вплинути на систему освіти. Турецька школа кінця ХХ століття суттєво відрізнялась від тієї, якою була десятками років раніше. Виділено наступні тенденції змін у системі освіти: збільшення нерівномірності рівня освіти, викликане соціальними та регіональними диференціаціями, для ліквідації яких держава не вживала жодних заходів; демонополізація та часткова децентралізація управління школою, що передбачало створення приватних навчальних закладів усіх рівнів; введення нових програм, що дозволило поглибити інтегративність навчання та виховання, і в результаті вивести турецьку середню освіту на рівень європейського стандарту середньої освіти тощо. 
Варто зазначити, що децентралізація управління освітою - характерна риса освітніх систем різних країн. У європейському звіті про якість шкільної освіти децентралізація освіти визначена як одна 3 п'яти ключових проблем майбутнього. У ньому зазначено, що перенесення процесу прийняття рішень на рівень школи є важливою політичною стратегією, яка викликана недостатністю довіри до здатності держави адекватно реагувати на потреби вимогливого населення [8]. Кінцевою метою модернізації освіти в Туреччині є підвищення якості освіти, майстерності педагогів, наближення освіти до європейських стандартів. Незаперечним є факт, що ефективність, переваги та успіх проведення освітніх реформ в Туреччині залежить, в першу чергу, від належного фінансування. Ключову роль у реформуванні турецької освіти впродовж останніх 35 років відіграли різні органи управління системою освіти. Зупинимося детальніше на них.

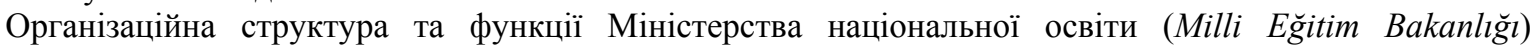
регулюється Законом про організацію та обов’язки Міністерства національної освіти (Milli Eğitim Bakanlığı'nın Teşkilat ve Gorevleri Hakkında Kanun) № 3397, згідно якого організаційна структура Міністерства національної освіти складається з чотирьох основних напрямів: центральна, провінційна, іноземна організації та підзвітні їм установи.

Згідно поняттю про державне керівництво в Туреччині, централізоване управління значно впливає на освіту. Центральна організація включає Раду з питань освіти Туреччини (Talim ve Terbiye Kurulu - TTK), головні управління (Головне управління з питань початкової освіти -lkoğretim Genel Mudurluğu, Головне управління з питань середньої освіти - Orta Oğretim Genel Mudurluğu vb ma інші), додаткові відділи та постійні ради.

Провінційна управлінська система передбачає поширення центральної системи управління освітою на місцевому рівні (провінції та райони), але регіональних відділів у цій структурі немає. В кожній провінції чи районі розташовуються правління з питань національної освіти (Milli Eğitim Mudurluğu), члени яких прирівнюються до державних чиновників (в провінціях - це губернатор (мер). Губернаторство $\epsilon$ втіленням розпоряджень та директив, отриманих від Міністерства національної освіти [9; 10]

Усі навчальні заклади є підпорядкованими Управлінню з питань національної освіти (Milli Eğitim Mudurluğu), тому і в кадрових питаннях та питаннях, що стосуються бюджету, шкільна адміністрація цілком залежить від центрального органу управління освітою i, як наслідок, повноваження освітнього закладу стосовно створення джерел самозабезпечення та формування штату працівників $є$ обмеженими. Директори освітніх закладів, крім директорів Анатолійських шкіл, призначаються на посаду губернаторами. А директори та вчителі Анатолійських шкіл призначаються на посади безпосередньо центральним органом управління освітою [11].

Крім центральної та провінційної організацій Міністерства національної освіти, також існує іноземна організація (консалтинг у сфері освіти, кабінети аташе 3 питань освіти та ін.) та дочірні установи Міністерства національної освіти.

Центральна організація Міністерства національної освіти включає членів міністерства, головні відділи, консультаційні та наглядові відділи, додаткові відділи та постійні ради.

Міністр (Bakan) відповідає за надання послуг, які пропонує Міністерство національної освіти згідно законодавства, основної політики країни та політики з питань національної безпеки, планів розвитку та щорічних програм. Міністр забезпечує співпрацю та узгодження низки спільних питань 3 іншими міністерствами та організаціями. Заступник міністра освіти (Musteşar) відповідає за організацію та виконання послуг, які надає міністерство згідно цілей та політики Міністерства національної освіти, планів розвитку, річних програм та положень законодавства за та від імені міністра.

Турецька Рада $з$ питань освіти (Talim ve Terbiye Kurulu) на сьогодні $є$ безпосереднім науковоконсультативним органом, який має право приймати рішення щодо усіх питань пов'язаних з освітою. Рада 3 питань освіти має наступні структурні підрозділи - відділи, які займаються освітою та навчальними планами, адміністративним управлінням, питаннями системи освіти та принципів її роботи, перевірками та розробкою нового планування тощо. Варто зазначити, що Рада $з$ питань освіти виступає ініціатором та організатором проведення досліджень, пов'язаних 3 системою освіти, навчальними планами та матеріалами, зокрема гарантуванням їх подальшої розробки та затвердженням внесення відповідних змін до них; виданням підручників та додаткових навчальних матеріалів відповідно до навчального плану; рецензуванням, внесенням змін та затвердженням навчальних планів, підручників, додаткових навчальних матеріалів, посібників для вчителів, підготовлених відповідними відділами Міністерства; аналізом тенденцій у вітчизняній та зарубіжній освіті, оцінкою можливостей культурного обміну; розробкою положень щодо гарантій підвищення кваліфікації викладацького штату та адміністративного (Закон з питань організації та обов'язків Міністерства національної освіти, стаття 8). Сьогодні Рада є головним органом, відповідальним за проведення шкільної реформи та підготовку нових навчальних програм для 1-го, 5-го та 9-го класів, що набрали чинності з вересня 2017 року.

Закон $з$ питань організації та обов'язків Міністерства національної освіти (стаття 9) передбачає створення наступних підрозділів, які приймають рішення з приводу адміністративних питань у сфері 
освіти, зокрема головних управлінь з питань дошкільної освіти (Okul Oncesi Ĕ̆itimi Genel Mudurluğu), 3 питань початкової освіти (İlkoğretim Genel Mudurluğu), з питань середньої освіти (Ortaoğretim Genel Mudurluğu), з питань професійної та технічної освіти для юнаків та дівчат (Erkek Teknik Ŏgretim Genel Mudurluğu), а також головних управлінь з питань освіти у сфері торгівлі та туризму (Ticaret ve Turizm Ŏgretimi Genel Mudurluğu), $з$ питань підготовки вчителів (Ŏgretmen Yetiştirme ve Eğitimi Genel Mudurluğu), з питань релігійної освіти (Din Oğretimi Genel Mudurluğu), приватних освітніх установ (Ozel Ŏgretim Kurumlarl Genel Mudurluğu) та 3 питань неформальної освіти (Clraklık ve Yaygın Eğitim Genel Mudurluğu)

Серед напрямків реформування середньої освіти, можемо виділити наступні: перехід до 13-ти річної обов'язкової освіти $(1+4+4+4)$; скасування курсів "національної безпеки" та "історії революції і революційних принципів Ататюрка", відміну домашніх завдань, але введення списку обов'язкової для прочитання літератури, обов'язкових до перегляду фільмів для вчителів, зменшення навчального навантаження на учнів тощо [12]. Створення нового курикулуму передбачає акцент на національні цінності та вивчення внеску в науку турецьких та мусульманських вчених, що дозволяє поєднати елементи євроцентризму з національною ідеєю розвитку освіти Туреччини.

Збільшенню кількості учнів в "школах імамів" сприяла реформа освіти 2012 року (4+4+4), в рамках якої запроваджувалася система обов'язкової 12-річної середньої освіти, що включала початкову, середню і старшу школи. В рамках проведених реформ 2005-2012 рр. розширювався "мусульманський контент" навчальних програм в державних і приватних освітніх закладах, зокрема курс "Ісламу" було виключено зі шкільних програм, введено курс "Релігійної культури та моральних цінностей", який передбачав вивчення Корану та норм ісламської моралі, збільшуючи кількість годин у курикулумі з 1 до 2 годин на тиждень за рахунок інших предметів. Дискусії щодо введення / виключення курсів "Релігійної культури та моральних цінностей", "Життя пророка Мухаммеда", "Читання Корану", "Історії ісламу" тривають і до цього часу, збільшуючи частку цих курсів до 6 годин релігійної освіти на тиждень навіть в стінах загальноосвітньої світської школи.

Консультативні та наглядові підрозділи(відділи) займаються науковою, пошуковою діяльністю у сфері адміністративних питань - Адміністрація наглядової ради (Teftiş Kurulu Başkanlığı), Адміністрація 3 питань стратегічного розвитку (Strateji Geliştirme Başkanlı̆̆l). Адміністрація наглядової ради проводить наглядову, наукову, дослідницьку та діагностувальну роботу для та від імені Міністра, згідно його наказу чи дозволу, пов'язану з організацією Міністерства та всіх підзвітних йому установ (Закон 3 питань організації та обов'язків Міністерства національної освіти; стаття 26). Адміністрація 3 питань стратегічного розвитку забезпечує організацію та проведення досліджень 3 метою визначення довгострокових та короткострокових стратегій та політики у системі управління освітою та визначення ії перспектив в рамках стратегій та політики національного розвитку, річних та урядових планів розвитку; дослідження зовнішніх факторів, які можуть впливати на якість освітніх послуг (Закон 3 питань організації та обов’язків Міністерства національної освіти; стаття 7)

В системі центральної організації Міністерства національної освіти є постійні ради - ради директорів (Milli Eğitim Şurası, Müdürler Kurulu), які включають до свого складу керівників відділів, таким чином формуючи центральну організацію Міністерства національної освіти 3 метою розробки та прийняття консультативних положень; ради з питань стажування та професійної освіти (Mesleki Eğitim Kurulu), студентські дисциплінарні ради (Öğrenci Disiplin Kurullarl) та спеціальні експертні комісії (Özel İhtisas Komisyonlarl). Національна Рада 3 питань освіти (Milli Eğitim Şurası) - є найвищою консультативною радою Міністерство національної освіти.

Контроль за освітнім процесом здійснюється на рівні Адміністрації Наглядової Ради (Teftiş Kurulu Başkanlığı) та наглядових рад 3 питань початкової освіти. За розпорядженням та підтвердженням Міністра, Рада здійснює нагляд, аналіз, вивчення та дослідження центральних, провінційних та іноземних освітніх установ (Положення Міністерства національної освіти 3 питань Наглядової Ради, стаття 5); організовує проведення перевірок в освітніх закладах, вживає необхідні заходи для усунення методичних недоліків; протидіє випадкам корупції або порушення законодавства (стаття 10).

Важливим моментом реформування системи освіти Туреччини є створення Національної академії освіти 15 липня 2005 року (Наказ № 1327), метою якої є організація підготовки фахівців для управління та контролю за навчально-виховним процесом освітніх закладів.

Висновки та перспективи подальшого дослідження проблеми. Головним інвестором в сфері освіти Туреччини є держава, тому як реформування системи освіти, так і державні витрати на середню освіту у відсотках від загального обсягу державних витрат на освіту досягають європейських та світових тенденцій. Однією з особливостей реформування системи освіти Туреччини є реалізація ідей сучасного розвитку освіти на всіх рівнях управління освітою; одночасне поєднання державного контролю освітніх реформ та децентралізації, інтернаціоналізації освіти із національною ідеєю, а також врахування релігійних та етнічних особливостей різних груп населення; відмова від застарілих методик виховання та 
боротьба з пережитками "часів військових переворотів"; актуалізація курикулуму та навчальних програм у відповідності до сучасних реалій тощо.

\section{СПИСОК ВИКОРИСТАНИХ ДЖЕРЕЛ ТА ЛІТЕРАТУРИ}

1. Система державного управління Турецької Республіки : досвід для України / уклад. П. Крайнік ; за заг. ред. Ю. Ковбасюка, С. Загороднюка. - К. : НАДУ, 2012. - 52 с.

2. The Constitution of the Republic of Turkey [Електронний ресурс]. - 224 с. - Режим доступу: http://global.tbmm.gov.tr/docs/constitution_en.pdf. - Accessed November 18, 2013.

3. The Basic Law of National Education [Електронний ресурс]. - Режим доступу: http://mevzuat.meb.gov.tr/html/88.html. - Accessed November 18, 2013.

4. The Law for the Unification of Education [Електронний ресурс]. - Режим доступу : http://mevzuat.meb.gov.tr/html/110.html. - Accessed November 18, 2013.

5. MEB 2004 Mali Yılı Bütçe Tasarısına li kin Rapor (Government Proposal for the 2004 Fiscal Year Education Budget). - Ankara : MEB, APK, 2003

6. MEB (MONE) - DPT (SPO) ; Eğitim Ana Plânı : 1996-2010; (Education Master Plan: 1996-2010) (Restricted Distribution). - Ankara : MEB Araştırma ; Plânlama ve Koordinasyon Kurulu, 1996

7. Aksit N. Educational Reform in Turkey / N. Aksit // International Journal of Educational Development. - 2007. P. $129-137$.

8. Ozden M. Problems with Science and Technology Education in Turkey [Електронний ресурс] / M. Ozden // Eurasia Journal of Mathematics, Science \& Technology Education. - 2007. - No. 3 (2). - P. 157-161. - Режим доступу : http://www. ejmste.com/v3n2/EJMSTE_v3n2_Ozden.pdf.

9. Öztaş S. Sosyal Bilgiler Öğretimi / S. Öztaş. - Pegem Ak kademi, Ankara, 2015.

10. Safran M. Özel Öğretim Yöntemleriyle Sosyal Bilgiler Öğretimi / M. Safran. - Pegem Akademi, Ankara, 2015.

11. Ulusoy K. ve ARSLAN, A. Farklı Yönleriyle Değerler Eğitimi. - Pegem Akademi, Ankara, 2014.

12. Турецкая культура : закон об обязательном 12-летнем образовании [Электронный ресурс]. - Режим доступа : http://www.rusorient.ru/page.php?vrub=rm\&vid=2025.

\section{REFERENCES (TRANSLATED \& TRANSLITERATED)}

1. Systema derzhavnogo upravlinnia Turetskoi Respubliki : dosvid dlia Ukraini [The System of Public Administration of the Republic of Turkey : Experience for Ukraine] / uklad. P. Kraynik; za zag. red. Yu. Kovbasiuka, S. Zagorodniuka. - K. : NADU, 2012. $-52 \mathrm{~s}$.

2. The Constitution of the Republic of Turkey [Elektronniy resurs]. - 224 s. - Rezhym dostupa : http://global.tbmm.gov.tr/docs/constitution_en.pdf. - Accessed November 18, 2013.

3. The Basic Law of National Education [Elektronnyi resurs]. - Rezhym dostupa : http://mevzuat.meb.gov.tr/html/88.html. - Accessed November 18, 2013.

4. The Law for the Unification of Education [Elektronnyi resurs]. - Rezhym dostupa : http://mevzuat.meb.gov.tr/html/110.html. - Accessed November 18, 2013.

5. MEB 2004 Mali Yılı Bütçe Tasarısına _li_kin Rapor (Government Proposal for the 2004 Fiscal Year Education Budget). - Ankara : MEB, APK, 2003

6. MEB (MONE) - DPT (SPO) ; Eğitim Ana Plânı: 1996-2010; (Education Master Plan : 1996-2010) (Restricted Distribution). - Ankara : MEB Araştırma; Plânlama ve Koordinasyon Kurulu, 1996

7. Aksit N. Educational Reform in Turkey / N. Aksit // International Journal of Educational Development. - 2007. P. 129-137.

8. Ozden M. Problems with Science and Technology Education in Turkey [Elektronnyi resurs] / M. Ozden // Eurasia Journal of Mathematics, Science \& Technology Education. - 2007. - No. 3 (2). - P. 157-161. - Rezhym dostupu : http://www. ejmste.com/v3n2/EJMSTE_v3n2_Ozden.pdf.

9. Öztaş S. Sosyal Bilgiler Öğretimi / S. Öztaş. - Pegem Akademi, Ankara, 2015.

10. Safran M. Özel Öğretim Yöntemleriyle Sosyal Bilgiler Öğretimi / M. Safran. - Pegem Akademi, Ankara, 2015.

11. Ulusoy K. ve ARSLAN, A. Farklı Yönleriyle Değerler Eğitimi. - Pegem Akademi, Ankara, 2014.

12. Turetskaia kul'tura : zakon ob obiazatel'nom 12-letnem obrazovanii [Turkish Culture : the Law on Compulsory 12year Education] [Elektronnyi resurs]. - Rezhym dostupa : http://www.rusorient.ru/page.php?vrub=rm\&vid=2025.

\section{Кючюк С. Реформирование системы среднего образования Турции на современном этапе: организация и управление.}

Статья посвящена анализу реформ среднего образования Турции на современном этапе. Автор обобщает процессы структурирования образования на всех государственных уровнях, рассматривает влияние государства на реформирование общего среднего образования, определяет причинноследственные связи основных черт инновачионных образовательных процессов в структуре системы образования, ее содержании, путях управления и финансирования, контроля и оценки знаний, умений учащихся общеобразовательных учреждений, анализирует влияние социально-экономической ситуации Туриии на становление общего среднего образования.

Ключевые слова: образование, общее среднее образование, образовательные реформы, демократизация, национализация. 


\section{Kucuk S. Reform of Turkey's Secondary Education System at the Present Moment: Organization and Management.}

The article is devoted to the analysis of secondary education reforms in Turkey at the present moment. The necessity for strengthening the reforming process in Turkish education has been widely acknowledged in the numerous education studies conducted at the past and at the present moment. The author summarizes the processes of structuring education at all government levels, examines the government influence on the reform of general secondary education, determines the causal relationships of the main features of innovative educational processes in the structure of the education system, its content, management and financing, control and evaluation of students' knowledge and abilities in general educational institutions, analyzes the influence of the social and economic situation of Turkey on the formation of general secondary education. The education changes based on the "4+4+4" formula provides compulsory 12-year education. Reform of Turkey's secondary education system considers the ways in which structural changes and practice have developed in response to a rapidly changing educational scenario over the last decade to meet the ever-growing and changing demands of Turkish society, policy-makers and other stakeholders and considers future developments. The possibility of successfully restructuring secondary education in its entirety depends on the presence of a public demand for reform in education and on what Turkish as a nation thinks it takes to achieve reform.

Key words: education, general secondary education, educational reforms, democratization, nationalization. 